\title{
Development and Validation of a HPLC Method for the Determination of Aldicarb, Aldicarb Sulfoxide and Aldicarb Sulfone in Liquid Samples from Anaerobic Reactors
}

\author{
Leonardo H. S. Damasceno, * M. Angela T. Adorno, Julia S. Hirasawa, \\ M. Bernadete A. Varesche and Marcelo Zaiat
}

\author{
Departamento de Hidráulica e Saneamento, Escola de Engenharia de São Carlos, Universidade de São Paulo, \\ Bloco 4F, Av. João Dagnone, 1100, Santa Angelina, 13563-120 São Carlos-SP, Brazil
}

\begin{abstract}
Este trabalho descreve o desenvolvimento e validação de um método de detecção de aldicarbe e seus metabólitos por cromatografia líquida de alta eficiência (HPLC) em amostras líquidas sem pré-tratamento. O sistema HPLC foi equipado com coluna C-18 e fase móvel composta de água e acetonitrila empregando gradiente de eluição linear. O detector UV foi operado em $210 \mathrm{~nm}$. Metomil foi utilizado como padrão interno. Água e meio sintético foram utilizados como solventes. O método foi linear de $0,49-15,0 \mathrm{mg} \mathrm{L}^{-1}\left(\mathrm{r}^{2}>0,9985\right), 0,1-5,0 \mathrm{mg} \mathrm{L}^{-1}\left(\mathrm{r}^{2}>0,9974\right)$ e $0,1-5,0 \mathrm{mg} \mathrm{L}^{-1}$ $\left(\mathrm{r}^{2}>0,9987\right)$ para o aldicarbe, sulfóxido de aldicarbe e sulfona de aldicarbe, respectivamente. A linearidade do método foi confirmada pelo teste F (ANOVA) através dos testes de ajuste do modelo linear, validade da regressão e eficiência da regressão. Os limites de detecção na água e em meio sintético foram de 0,391/0,440 $\mathrm{mg} \mathrm{L}^{-1}, 0,069 / 0,192 \mathrm{mg} \mathrm{L}^{-1}$ e $0,033 / 0,068 \mathrm{mg} \mathrm{L}^{-1}$ para o aldicarbe, sulfóxido de aldicarbe e sulfona de aldicarbe, respectivamente. O tempo total de análise foi de 22 minutos. Na aplicação do método, avaliou-se a degradação do aldicarbe no reator anaeróbio horizontal de leito fixo (RAHLF) em diferentes condições operacionais (metanogênese, sulfetogênese e desnitrificação).
\end{abstract}

This study describes the development and validation of a high-performance liquid chromatography (HPLC) method for detecting aldicarb and its residues in liquid samples without pretreatment. The HPLC system was equipped with a C-18 column and the mobile phase was composed of a mixture of water and acetonitrile using a linear gradient elution. The UV detector was utilized at $210 \mathrm{~nm}$. Methomyl was used as an internal standard. Water and synthetic medium were used as solvents. The method was linear from 0.49-15.0 $\mathrm{mg} \mathrm{L}^{-1}\left(\mathrm{r}^{2}>0.9985\right), 0.1-5.0 \mathrm{mg} \mathrm{L}^{-1}$ $\left(r^{2}>0.9974\right)$ and $0.1-5.0 \mathrm{mg} \mathrm{L}^{-1}\left(r^{2}>0.9987\right)$ for aldicarb, aldicarb sulfoxide and aldicarb sulfone, respectively. The linearity of the method was confirmed by the ANOVA F-test through adjustment of the linear model, validity of the regression and efficiency of the regression tests. The limit of detection in water and synthetic medium were of $0.391 / 0.440 \mathrm{mg} \mathrm{L}^{-1}, 0.069 / 0.192 \mathrm{mg} \mathrm{L}^{-1}$ and 0.033/0.068 $\mathrm{mg} \mathrm{L}^{-1}$ for aldicarb, aldicarb sulfoxide and aldicarb sulfone, respectively. Total time of analysis was of $22 \mathrm{~min}$. In the application of the method, the aldicarb degradation in horizontalflow anaerobic immobilized biomass (HAIB) reactor was evaluated under different conditions (methanogenic, sulfidogenic and denitrifying).

Keywords: aldicarb, bioremediation, carbamate, HPLC, validation

\section{Introduction}

Aldicarb, the active ingredient in $\mathrm{Temik}^{\circledast}$, is the common name for 2-methyl-2-(methylthio)propionaldehyde $\mathrm{O}$-(methylcarbamoyl)-oxime, represented by the molecular formula $\mathrm{C}_{7} \mathrm{H}_{14} \mathrm{~N}_{2} \mathrm{O}_{2} \mathrm{~S}$. It is a systemic carbamate insecticide of broad-spectrum used to control a variety of insects, mites and nematodes. It inhibits the action

*e-mail: leonardo@eafudi.gov.br of acetylcholinesterase (AChE), which is an essential enzyme of a common metabolic pathway shared by insects and mammalians. ${ }^{1}$

The high mobility of aldicarb and its residues (aldicarb sulfoxide and aldicarb sulfone) is due to their low sorption coefficients. In thin soil layer or under specific conditions (high water table, sandy soils, low $\mathrm{pH}$, low temperature, high rainfall, irrigation practices etc.) the use of aldicarb can result in a potential problem for groundwater contamination. ${ }^{2}$ Moreover, the use of pesticides can be 
potentially hazardous as a result of accidental spills and runoff from areas of application. ${ }^{3}$

In United States, aldicarb, aldicarb sulfoxide and aldicarb sulfone were detected in groundwater in the range of 0.08-1264.00 $\mu \mathrm{g} \mathrm{L}^{-1}, 0.01-1030.00 \mu \mathrm{g} \mathrm{L}^{-1}$ and 0.08-153.00 $\mu \mathrm{g} \mathrm{L}^{-1}$, respectively. ${ }^{4}$ In Brazil, the lack of an integrated management program of groundwater does not allow the control of the pollution caused by pesticides. ${ }^{5}$ However, the aldicarb was detected in maximum concentration of $5 \mu \mathrm{g} \mathrm{L}^{-1}$ in rural water supply. ${ }^{6}$

In the presence of microorganisms, aldicarb degradation occurs by two routes: oxidation to aldicarb sulfoxide and later to aldicarb sulfone (aerobic conditions); or hydrolysis of aldicarb and its residues to the corresponding oximes (anaerobic conditions). ${ }^{1}$

Aldicarb and its oxidation products can be determined in terms of their nitrile derivatives by capillary gas chromatography with a nitrogen-phosphorus detector. ${ }^{7}$ On the other hand, gas chromatographic procedures are difficult to perform due to several factors: (i) many of these compounds are thermally unstable, (ii) samples must be extracted and treated before analysis, and (iii) speciation of the residues requires an additional liquid chromatographic clean-up step. ${ }^{8}$ The determination of carbamates by capillary electrophoresis (CE) ${ }^{9}$ and micellar electrokinetic chromatography (MEKC) ${ }^{10}$ has also been reported.

Aldicarb and its degradation products in water may be determined by high-performance liquid chromatography (HPLC). ${ }^{11}$ HPLC offers a simple and rapid method for determination of aldicarb and its residues. ${ }^{8}$

EPA Method 531.1 is applicable to the determination of certain $\mathrm{N}$-methylcarbamoyloximes and $\mathrm{N}$-methylcarbamates in groundwater and finished drinking water. This method employs the direct analysis of a water sample with a HPLC separation and post-column derivatization to a compound detected with a fluorescence detector. ${ }^{12}$ The filtered sample $(400 \mu \mathrm{L})$ is injected into a reversed-phase HPLC column. Separation of the analytes is achieved using methanol and water as the mobile phase in gradient elution. After elution, the analytes are hydrolyzed with $0.05 \mathrm{~mol} \mathrm{~L}^{-1}$ sodium hydroxide $(\mathrm{NaOH})$ at $95{ }^{\circ} \mathrm{C}$. The methylamine formed is then reacted with $o$-phthalaldehyde (OPA) and 2-mercaptoethanol to form a highly fluorescent derivative which is measured by a fluorescence detector.

A method to determine an aldicarb and its residues by HPLC with UV detection $(\lambda=200 \mathrm{~nm})$ in groundwater samples without pretreatment was developed earlier. ${ }^{8}$ Acetonitrile and water were used as the mobile phase in two isocratic runs (12:88/40:60) to separate all aldicarb compounds (aldicarb, aldicarb sulfoxide, aldicarb sulfone and its respective nitriles and oximes). This protocol was adapted by using gradient elution in a single chromatographic run and using methomyl as an internal standard. ${ }^{13}$

In HPLC systems, different detectors have been evaluated, such as electrospray mass spectrometry (ESMS $)^{14}$ and atmospheric pressure chemical ionization mass spectrometry (APCI-MS) $\cdot{ }^{15}$ Although the precision increases with the use of these techniques, the cost of the equipment is significant.

Usually, the methods involve extraction or other sample preparation steps (solid-phase extraction (SPE) ${ }^{10,14,15}$ or liquid-liquid extraction (LLE) ${ }^{15}$ ) that can cause spurious results and that are time-consuming. Simpler approaches that do not require additional handling or previous sample preparation are reported to affect positively the precision of the chemical determination and experimental errors are reduced. ${ }^{8}$ Therefore, the purpose of this work was to develop and validate a HPLC method for determination of aldicarb, aldicarb sulfoxide and aldicarb sulfone in liquid samples without pretreatment. This method was applied to evaluate the degradation of aldicarb in a packed-bed anaerobic reactor under different conditions (methanogenic, sulfidogenic and denitrifying).

\section{Experimental}

\section{Instrumentation and analytical conditions}

A Shimadzu ${ }^{\circledR}$ liquid chromatography system equipped with a $\mathrm{LC}-10 \mathrm{AD}_{\mathrm{VP}}$ pump, a FCV-10AL $\mathrm{L}_{\mathrm{VP}}$ valve, an ultraviolet detector with diode array (SPD-M10 $\mathrm{A}_{\mathrm{VP}}$ ), a controller SCL-10A $\mathrm{AP}_{\mathrm{vP}}$ and a Rheodyne injector $(100-\mu \mathrm{L}$ loop) was used. The HPLC was equipped with an Agilent Zorbax ODS ${ }^{\circledast}$ C-18 column (mesh size: $5 \mu \mathrm{m}$; length: $25 \mathrm{~cm}$; internal diameter: $4.6 \mathrm{~mm}$ ). Aldicarb and its residues were separated by using a linear gradient elution program and the mobile phase was a mixture of water and acetonitrile (Table 1). The flow rate was $1.2 \mathrm{~mL} \mathrm{~min}^{-1}$ and the temperature of the oven was $40^{\circ} \mathrm{C}$. The UV detector was fixed at $\lambda=210 \mathrm{~nm}$. The methomyl was used as an internal standard. This protocol was a modification of a procedure reported earlier. ${ }^{8,13}$

Table 1. HPLC programming showing the gradient of the mobile phase used to determine aldicarb and its residues

\begin{tabular}{lcc}
\hline time / min & Solvent A \% & Solvent B \% \\
\hline 0 & 80 & 20 \\
4 & 60 & 40 \\
13 & 45 & 55 \\
15 & 80 & 20 \\
22 & STOP & STOP \\
\hline
\end{tabular}

Solvent A: Water; Solvent B: Acetonitrile. 


\section{Chemicals and solvents}

Analytical standards of aldicarb (purity 99\%), aldicarb sulfoxide (purity 99\%), aldicarb sulfone (purity 99\%) and methomyl (purity 95\%) were obtained from Radian International $^{\circledR}$, Ultra Scientific ${ }^{\circledR}$, ChemService ${ }^{\circledR}$ and AccuStandard ${ }^{\circledR}$, respectively. The acetonitrile was obtained from JT Baker ${ }^{\circledR}$ (HPLC-grade) and the water was ultrapurified in a Millipore MilliQ ${ }^{\circledR}$ system.

\section{Preparation of samples}

The samples were prepared in glass volumetric flasks $(5 \mathrm{~mL}$ ) by addition of $200 \mu \mathrm{L}$ of a solution of methomyl in water $\left(115.2 \mathrm{mg} \mathrm{L}^{-1}\right)$ and by dilution of different volumes of samples $(2,3$ or $4 \mathrm{~mL})$ in ultra-purified water. Before the injection, the samples were passed through a $0.2 \mu \mathrm{m}$ pore-size Millipore ${ }^{\circledR}$ filter.

\section{Method validation}

The HPLC method was validated by the determination of its precision within the linear range of the data, instrumental precision, and limits of detection (LOD) and quantification (LOQ) according to methodology developed previously. ${ }^{16}$ The standard calibration curves were obtained by the dilution of three reference standard solutions $\left(94.4 \mathrm{mg} \mathrm{L}^{-1}\right.$, $20 \mathrm{mg} \mathrm{L}^{-1}$ and $20 \mathrm{mg} \mathrm{L}^{-1}$, for aldicarb, aldicarb sulfoxide and aldicarb sulfone, respectively) with three replicates each. The dilution was made in ultra-purified water and in synthetic medium ${ }^{17}$ to obtain the concentrations shown in Table 2.

Table 2. Concentrations of analytes used in standard calibration curves

\begin{tabular}{ll}
\hline Analyte & Concentrations $/\left(\mathrm{mg} \mathrm{L}^{-1}\right)$ \\
\hline Aldicarb & $0.49 ; 1.0 ; 2.49 ; 5.0 ; 10.0 ; 11.99 ; 15.0$. \\
Aldicarb sulfoxide & $0.1 ; 0.3 ; 0.5 ; 1.0 ; 2.0 ; 4.0 ; 5.0$. \\
Aldicarb sulfone & $0.1 ; 0.3 ; 0.5 ; 1.0 ; 2.0 ; 4.0 ; 5.0$. \\
\hline
\end{tabular}

\section{Linearity}

The linearity of the detector response for the prepared standards was assessed by means of linear regression analysis (least-square regression method), for the amounts of each standard, measured in $\mathrm{mg} \mathrm{L}^{-1}$, and its response factor (RF) (area of the corresponding peak/area of methomyl). The statistical significance of regression was evaluated using the ANOVA table constructed from equations shown in Table 3 and by adjustment of the linear model (ALM), validity of the regression (VR) and efficiency of the regression (ER) tests (Table 4), according to method developed previously. ${ }^{18,19}$

Table 3. Mean sum of squares and degrees of freedom used in F-test (ANOVA)

\begin{tabular}{|c|c|c|c|}
\hline Source of variability & Sum of squares & Degrees of Freedom & Mean Sum of Squares \\
\hline Total & $\mathrm{SQT}=\Sigma \Sigma \mathrm{y}_{\mathrm{ij}}{ }^{2}$ & $\mathrm{n}$ & $\mathrm{MQT}=\mathrm{SQT} / \mathrm{n}$ \\
\hline Correction (“b”) & $\mathrm{FC}=\mathrm{n}_{\mathrm{y}} \mathrm{y}_{00}^{2}$ & 1 & $\mathrm{FC}$ \\
\hline Total corrected & $\mathrm{SQC}=\Sigma \Sigma\left(\mathrm{y}_{\mathrm{ij}}-\mathrm{y}_{00}\right)^{2}$ & $\mathrm{n}-1$ & $\mathrm{MQC}=\mathrm{SQC} /(\mathrm{n}-1)$ \\
\hline Due to regression ("a") & $\mathrm{SQR}=\Sigma\left(\mathrm{y}_{\mathrm{i}}-\mathrm{y}_{00}\right)^{2}$ & 1 & $\mathrm{MQR}=\mathrm{SQR}$ \\
\hline Residual & $\mathrm{SQE}=\Sigma \Sigma\left(\mathrm{y}_{\mathrm{ij}}-\mathrm{y}_{\mathrm{i}}\right)^{2}$ & $\mathrm{n}-2$ & $\mathrm{MQE}=\mathrm{SQE} /(\mathrm{n}-2)$ \\
\hline Pure Error & $\mathrm{SQEP}=\Sigma \Sigma\left(\mathrm{y}_{\mathrm{ij}}-\mathrm{y}_{\mathrm{i} 0}\right)^{2}$ & $\mathrm{n}-\mathrm{m}_{\mathrm{i}}$ & $\mathrm{MQEP}=\mathrm{SQEP} /\left(\mathrm{n}-\mathrm{m}_{\mathrm{i}}\right)$ \\
\hline Lack-of-fit & $\mathrm{SQL}=\Sigma\left(\mathrm{y}_{\mathrm{i}}-\mathrm{y}_{\mathrm{i} 0}\right)^{2}$ & $m_{i}-2$ & $\mathrm{MQL}=\mathrm{SQL} /\left(\mathrm{m}_{\mathrm{i}}-2\right)$ \\
\hline
\end{tabular}

$\mathrm{n}=$ total number of measurements; $\mathrm{m}_{\mathrm{i}}=\mathrm{i}$-concentration levels $(7) ; \mathrm{y}_{\mathrm{ij}}=$ observed signal; $\mathrm{y}_{00}=$ mean of measured signals; $\mathrm{y}_{\mathrm{i}}=$ predicted dependent variable; $\mathrm{y}_{\mathrm{i} 0}=$ mean of replicates of $\mathrm{i}$-concentration level; " $\mathrm{i}$ " index refers to $\mathrm{x}$-independent variable; " $\mathrm{j}$ " index refers to replicates in $\mathrm{x}$-levels. First summation $\Sigma$ ranges from $i=1$ to $i=m_{i}$. Second summation $\Sigma \Sigma$ in SQC, SQE and SQEP ranges from $i=1$ to $j=n_{i}$.

Table 4. Linearity and regression efficiency tests

\begin{tabular}{|c|c|c|c|}
\hline Test & $\mathrm{F}_{\text {critical }}$ & $\mathrm{F}_{\text {obtained }}$ & Condition \\
\hline Adjustment of the linear model (ALM) & $\mathrm{F}_{\mathrm{mi}-2 ; \mathrm{n}-\mathrm{mi} ; / 2}$ & MQL/MQEP & $\mathrm{F}_{\text {obtained }}<\mathrm{F}_{\text {critical }}$ \\
\hline Validity of the regression (VR) & $\mathrm{F}_{1 ; \mathrm{n}-2 ; \alpha / 2}$ & MQR/MQE & $\mathrm{F}_{\text {obtained }} \gg \mathrm{F}_{\text {critical }}$ \\
\hline \multicolumn{4}{|c|}{ Efficiency of the regression (ER) } \\
\hline Efficiency $\left(r^{2}\right)$ & & SQR/SQC & \\
\hline Maximum efficiency $\left(\mathrm{r}^{2}{ }_{\text {max }}\right)$ & & SQC/SQEP & \\
\hline
\end{tabular}


Limit of Detection (LOD) and Limit of Quantification ( $L O Q)$

The LOD and LOQ for each standard were determined from the calibration curves, where the root mean square error (RMSE) was calculated according to the following expressions: ${ }^{20}$

$\mathrm{LOD}=(3 \times \mathrm{RMSE}) / m$

$\mathrm{LOQ}=(10 \times \mathrm{RMSE}) / m$

where RMSE is the root mean square error and $m$ is the slope of the linear regression equation.

\section{Precision}

The precision of the system was expressed as the coefficient of variation $(\mathrm{CV} \%)$ of the retention times for each standard, at different concentrations (Table 2).

\section{Instrumental precision}

The instrumental precision of the assay (as coefficient of variation, $\mathrm{CV} \%$ ) was estimated by the retention time of ten repeated injections of the standard solution in synthetic medium with aldicarb, aldicarb sulfoxide and aldicarb sulfone at concentrations of $4 \mathrm{mg} \mathrm{L}^{-1}$.

\section{Experimental samples collected from anaerobic packed-bed reactors treating aldicarb}

The method was evaluated through analysis of aldicarb and its residues in different liquid samples from influent and effluent streams of horizontal-flow anaerobic immobilized biomass (HAIB) reactors under different conditions (methanogenic, sulfidogenic and denitrifying). The $2 \mathrm{~L}$ HAIB reactors were composed of a $1.0 \mathrm{~m}$ glass tube with diameter of $5 \mathrm{~cm}$ and lengthto-diameter ratio (L/D) of $20 .{ }^{21}$ Intermediate sampling ports were allocated along the reactor at $\mathrm{L} / \mathrm{D}$ of $4,8,12$ and 16 . The three reactors were operated simultaneously at constant hydraulic detention time of 24 hours at a temperature of $30 \pm 1^{\circ} \mathrm{C}$. The synthetic medium contained aldicarb (from commercial product - Temik ${ }^{\circledR}$ ) as the sole carbon and energy source $\left(10 \mathrm{mg} \mathrm{L}^{-1}\right)$, besides solutions of salts, vitamins and trace metals. ${ }^{17}$ Sulphate $(36 \pm$ $\left.2 \mathrm{mg} \mathrm{L}^{-1}\right)$ and nitrate $\left(20 \pm 1 \mathrm{mg} \mathrm{L}^{-1}\right)$ were added in the sulfidogenic and denitrifying reactors, respectively. All reactors were filled with polyurethane foam cubic particles previously inoculated with anaerobic biomass. Aldicarb concentration data were obtained during operation to evaluate the process of degradation of aldicarb in anaerobic bioreactors.

\section{Results and Discussion}

\section{Determination of aldicarb, aldicarb sulfoxide and aldicarb sulfone}

The selected chromatographic conditions were ideal for the identification of individual peaks, resulting in good and well-resolved separation of the analytes, as can be seen in a typical chromatogram shown in Figure 1. It was necessary to use a delay of 2.3 minutes to avoid the

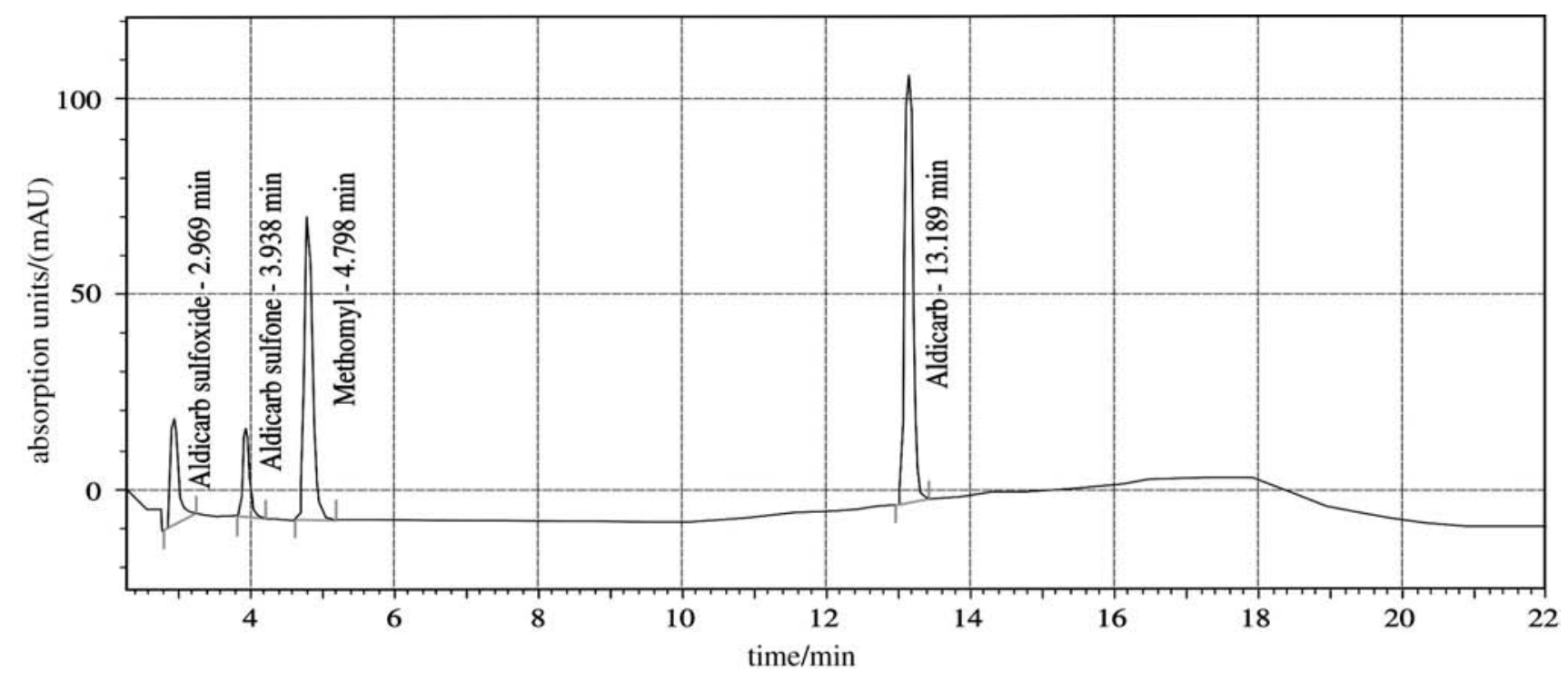

Figure 1. Liquid chromatography with UV detection of synthetic medium spiked with aldicarb sulfoxide, aldicarb sulfone and aldicarb at 1 mg $\mathrm{L}^{-1}$, $1 \mathrm{mg} \mathrm{L}^{-1}$ and $5 \mathrm{mg} \mathrm{L}^{-1}$, respectively. 
Table 5. Regression curves and regression efficiency tests

\begin{tabular}{lcccc}
\hline Analyte & Solution & Equation & $\mathrm{r}^{2}$ & $\mathrm{r}^{2}{ }_{\max }$ \\
\hline \multirow{2}{*}{ Aldicarb } & Water & $\mathrm{y}=0.2385 \mathrm{x}+0.0274$ & 0.9985 & 0.9989 \\
& Synthetic medium & $\mathrm{y}=0.2380 \mathrm{x}+0.0262$ & 0.9989 & 0.9995 \\
\hline \multirow{2}{*}{ Aldicarb sulfoxide } & Water & $\mathrm{y}=0.2458 \mathrm{x}-0.0125$ & 0.9996 & 0.9997 \\
& Synthetic medium & $\mathrm{y}=0.2590 \mathrm{x}+0.0611$ & 0.9974 & 0.9983 \\
Aldicarb sulfone & Water & $\mathrm{y}=0.2599 \mathrm{x}-0.0044$ & 0.9987 & 0.9987 \\
& Synthetic medium & $\mathrm{y}=0.2510 \mathrm{x}+0.0026$ & 0.9997 & 0.9998 \\
\hline
\end{tabular}

interference of substances that are present in the synthetic medium. Although aldicarb peak come off at $13.16 \mathrm{~min}$ (Table 8), it was necessary to flush the column to avoid interference between samples, returning to the initial gradient of the mobile phase. Tests had been carried through to minimize the time, however without success, either for the variation of the retention times or for the appearance of ghost peaks.

\section{Method validation}

The standard calibration curves in the investigated range were linear, both with water and with synthetic medium as solvents for the standard solutions. Table 5 summarizes the regression data of the calibration curves, squares of correlation coefficients $\left(\mathrm{r}^{2}\right)$ and maximum squares of correlation coefficients $\left(\mathrm{r}^{2}{ }_{\max }\right)$ of each analyte. Table 6 summarizes the results of linearity tests for a statistical significance of $95 \%$.

Table 6. Results of linearity tests for statistical significance at 95 percent

\begin{tabular}{|c|c|c|c|c|c|}
\hline \multirow[t]{2}{*}{ Analyte } & \multirow[t]{2}{*}{ Solution } & \multicolumn{2}{|c|}{ ALM } & \multicolumn{2}{|c|}{ VR } \\
\hline & & $\mathrm{F}_{5 ; 14 ; 0.025}$ & $\mathrm{~F}_{\text {obtained }}$ & $\mathrm{F}_{1 ; 19 ; 0.025}$ & $\mathrm{~F}_{\text {obtained }}$ \\
\hline \multirow[t]{2}{*}{ Aldicarb } & Water & & 1.07 & & 12298.07 \\
\hline & $\begin{array}{l}\text { Synthetic } \\
\text { medium }\end{array}$ & & 2.90 & & 17938.19 \\
\hline \multirow{2}{*}{$\begin{array}{l}\text { Aldicarb } \\
\text { sulfoxide }\end{array}$} & Water & & 1.12 & & 46388.27 \\
\hline & $\begin{array}{l}\text { Synthetic } \\
\text { medium }\end{array}$ & 3.66 & 1.46 & 5.92 & 7142.34 \\
\hline \multirow{2}{*}{$\begin{array}{l}\text { Aldicarb } \\
\text { sulfone }\end{array}$} & Water & & 0.06 & & 14921.74 \\
\hline & $\begin{array}{l}\text { Synthetic } \\
\text { medium }\end{array}$ & & 1.45 & & 56144.86 \\
\hline
\end{tabular}

According to method developed previously, ${ }^{18,19}$ in the adjustment of the linear model (ALM) test, if the F-test values obtained from ANOVA $\left(\mathrm{F}_{\text {obtained }}\right)$ are inferior to the statistical F-test values $\left(\mathrm{F}_{\text {critical }}\right)\left(\mathrm{F}_{\text {obtained }}<\mathrm{F}_{\text {critical }}\right)$, then the adjustment of the model is considered satisfactory. The validity of the regression (VR) test demonstrates that the slope of the linear regression equation is different than zero. If the F-test values obtained from ANOVA $\left(\mathrm{F}_{\text {obtained }}\right)$ are superior to the statistical F-test values $\left(\mathrm{F}_{\text {critical }}\right)\left(\mathrm{F}_{\text {obtained }}>>\right.$ $\left.\mathrm{F}_{\text {critical }}\right)$, it is an indication that the $\mathrm{m}$ value is not null. The results showed that the squares of the linear correlation coefficients were above 0.99 (Table 5), evidencing the linearity occurrence. ${ }^{22}$ The regression of standard curves in ultra-purified water and in synthetic medium was statistically significant since the statistical test did not exceed the critical value.

The values of $r^{2}$ and maximum squares of correlation coefficients $\left(\mathrm{r}_{\text {max }}^{2}\right)$ were similar. This indicates that the error due to regression is close to the pure error that must be due to the analytical procedure, validating the use of the linear model.

The LOD and LOQ values were smaller for the standard solutions in water than those obtained in synthetic medium as solvent (Table 7). The precision of the method and instrumental precision of the assay was estimated by coefficient of variation $(\mathrm{CV})$ of retention times (Table 8 ). The precision of the method was measured from standard calibration curves in synthetic medium, with CV lower than $3.32 \%$. The instrumental precision, estimated from ten injections of the same standard solution in synthetic medium, resulted in a range from $0.8 \%$ to $1.56 \%$. Values below $5 \%$ demonstrate the precision of the method. ${ }^{22}$

Table 7. Limit of detection (LOD) and limit of quantification (LOQ) of analytes in water and synthetic medium

\begin{tabular}{llcc}
\hline Analyte & Solution & LOD / $\left(\mathrm{mg} \mathrm{L}^{-1}\right)$ & LOQ / $\left(\mathrm{mg} \mathrm{L}^{-1}\right)$ \\
\hline \multirow{2}{*}{ Aldicarb } & Water & 0.391 & 1.303 \\
\cline { 2 - 4 } & $\begin{array}{l}\text { Synthetic } \\
\text { medium }\end{array}$ & 0.440 & 1.466 \\
\hline $\begin{array}{l}\text { Aldicarb } \\
\text { sulfoxide }\end{array}$ & Water & 0.069 & 0.230 \\
\cline { 2 - 4 } & $\begin{array}{l}\text { Synthetic } \\
\text { medium }\end{array}$ & 0.192 & 0.641 \\
\hline $\begin{array}{l}\text { Aldicarb } \\
\text { sulfone }\end{array}$ & Water & 0.033 & 0.109 \\
\cline { 2 - 4 } & $\begin{array}{l}\text { Synthetic } \\
\text { medium }\end{array}$ & 0.068 & 0.228 \\
\hline
\end{tabular}


Table 8. Precision and instrumental precision of method for each analyte in synthetic medium

\begin{tabular}{lcccc}
\hline Analyte & \multicolumn{2}{c}{ Precision } & \multicolumn{2}{c}{ Instrumental precision } \\
\cline { 2 - 5 } & $\mathrm{t}_{\mathrm{ret}} / \mathrm{min}^{\mathrm{a}, \mathrm{b}}$ & $\mathrm{CV} /(\%)^{\mathrm{b}}$ & $\mathrm{t}_{\mathrm{ret}} / \mathrm{min}^{\mathrm{a}, \mathrm{c}}$ & $\mathrm{CV} /(\%)^{\mathrm{c}}$ \\
\hline Aldicarb sulfoxide & $2.949 \pm 0.098$ & 3.32 & $2.946 \pm 0.038$ & 1.29 \\
Aldicarb sulfone & $3.988 \pm 0.084$ & 2.10 & $4.001 \pm 0.059$ & 1.47 \\
Methomyl & $4.873 \pm 0.098$ & 2.02 & $4.892 \pm 0.076$ & 1.56 \\
Aldicarb & $13.166 \pm 0.129$ & 0.982 & $13.270 \pm 0.106$ & 0.80 \\
\hline
\end{tabular}

a Retention times are mean \pm SD. ${ }^{b}$ Values obtained of standard calibration curves $(n=3)$. ${ }^{\mathrm{c}}$ Value obtained of repeated injections of the standard solution $(\mathrm{n}=10)$.

\section{Application}

Figure 2 shows the values of aldicarb concentrations in influent and effluent of the HAIB reactor in methanogenic, denitrifying and sulfidogenic conditions (to an initial concentration of $10 \mathrm{mg} \mathrm{L}^{-1}$ ). In the evaluation of the process, the degradation/removal of total aldicarb (TA) must be considered (sum of aldicarb, aldicarb sulfoxide and aldicarb sulfone). This consideration is common in studies with aldicarb, since these substances present similar toxicity and therefore have to be removed in the bioremediation process. The denitrifying reactor presented more stable TA removal than the other reactors, and with higher removal efficiency (Table 9).

At the beginning of the operation of the reactors, aldicarb sulfoxide and aldicarb sulfone were detected in the effluent streams. Later, this residues were not detected indicating the acclimatization of the anaerobic organisms to the established conditions. ${ }^{13}$ Their respective hydrolysis products, oximes and subsequent products, are much less toxic. ${ }^{1}$ Assuming the degradation of the non-detected compound, the toxicity was reduced, representing an advantage of these systems. (a)

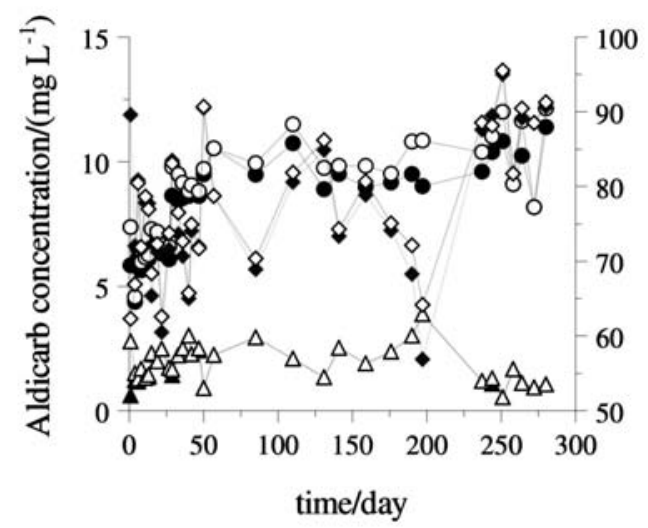

(b)

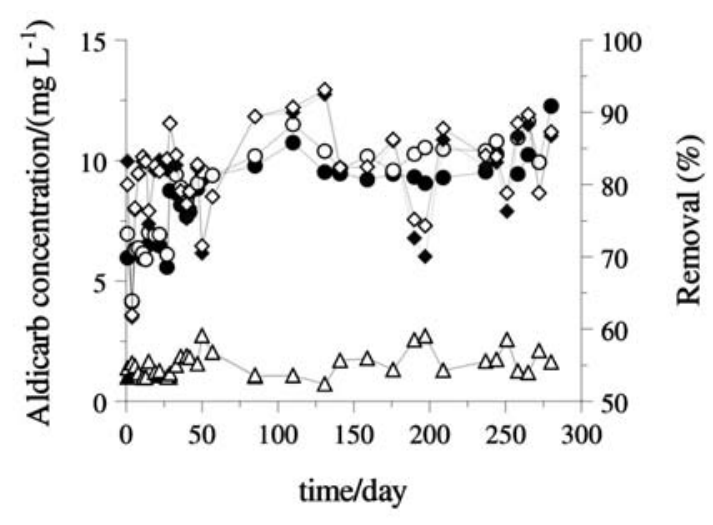

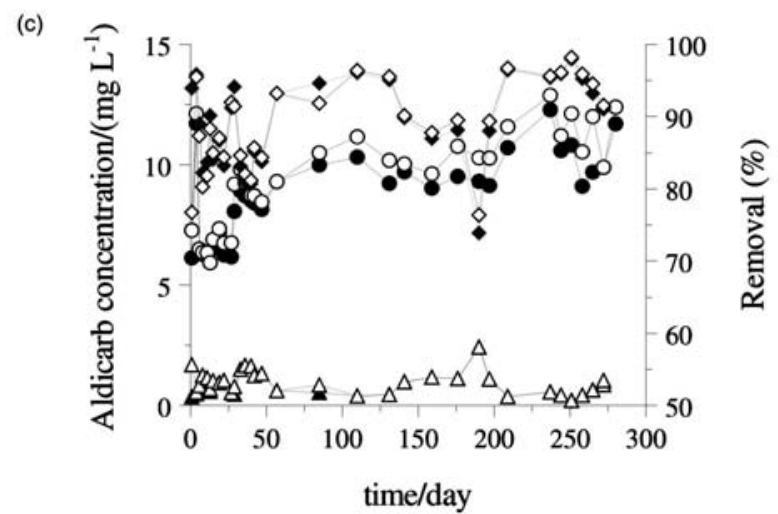

Figure 2. Temporal variation of aldicarb (influent - @; effluent - $\bigcirc$ )/total aldicarb (influent - $\mathbf{\square}$; effluent - $\square$ ) concentration and aldicarb (一)/total aldicarb (---) removal efficiency in methanogenic reactor (a), sulfidogenic reactor (b) and denitrifying reactor (c). 
Table 9. Aldicarb concentration and aldicarb removal efficiency in methanogenic, denitrifying and sulfidogenic reactors

\begin{tabular}{|c|c|c|c|c|c|c|}
\hline \multirow{3}{*}{ Reactor } & \multicolumn{4}{|c|}{ Concentration / $\left(\mathrm{mg} \mathrm{L}^{-1}\right)$} & \multicolumn{2}{|c|}{ Removal / (\%) } \\
\hline & \multicolumn{2}{|c|}{ Influent } & \multicolumn{2}{|c|}{ Effluent } & \multirow{2}{*}{ Aldicarb } & \multirow{2}{*}{ Total Aldicarb } \\
\hline & Aldicarb & Total Aldicarb & Aldicarb & Total Aldicarb & & \\
\hline Methanogenic & $8.1 \pm 1.8$ & $8.7 \pm 1.9$ & $2.0 \pm 0.8$ & $2.1 \pm 0.7$ & $75.6 \pm 9.4$ & $76 \pm 8.0$ \\
\hline Desnitrifying & $8.4 \pm 1.8$ & $9.0 \pm 1.9$ & $0.9 \pm 0.5$ & $1.0 \pm 0.5$ & $89.0 \pm 5.8$ & $88.5 \pm 5.2$ \\
\hline Sulfidogenic & $8.0 \pm 1.7$ & $8.5 \pm 1.9$ & $1.5 \pm 0.5$ & $1.6 \pm 0.5$ & $80.9 \pm 6.6$ & $81.8 \pm 5.9$ \\
\hline
\end{tabular}

\section{Conclusions}

The HPLC method for the determination of aldicarb, aldicarb sulfoxide and aldicarb sulfone in liquid samples without pretreatment was shown to be specific, precise and accurate. The generated chromatograms were ideal for the identification of individual peaks with significant correlation and reproducibility regarding their readings of standard solutions.

The statistical analysis demonstrated that the standard curves in the investigated range were linear, from 0.49$15.0 \mathrm{mg} \mathrm{L}^{-1}\left(\mathrm{r}^{2}>0.9985\right), 0.1-5.0 \mathrm{mg} \mathrm{L}^{-1}\left(\mathrm{r}^{2}>0.9974\right)$ and $0.1-5.0 \mathrm{mg} \mathrm{L}^{-1}\left(\mathrm{r}^{2}>0.9987\right)$ for aldicarb, aldicarb sulfoxide and aldicarb sulfone, respectively. The limit of detection in water and synthetic medium were of $0.391 / 0.440 \mathrm{mg} \mathrm{L}^{-1}$, $0.069 / 0.192 \mathrm{mg} \mathrm{L}^{-1}$ and $0.033 / 0.068 \mathrm{mg} \mathrm{L}^{-1}$ for aldicarb, aldicarb sulfoxide and aldicarb sulfone, respectively. Total time of analysis was of $22 \mathrm{~min}$.

The results provide evidence that the HPLC system and the method are adequate for monitoring biodegradation of aldicarb in anaerobic reactors.

\section{Acknowledgments}

This research was suppported by Fundação de Amparo à Pesquisa do Estado de São Paulo (FAPESP) (Process Number 03/10506-7) and Conselho Nacional de Desenvolvimento Científico e Tecnológico (CNPq) (Process Number 471764/20043). The authors are grateful to Bayer CropScience ${ }^{\circledR}$ for donation of the commercial product.

\section{References}

1. Andrawes, N. R.; Bagley, W. P.; Herret, R. A.; J. Agric. Food Chem. 1971, 19, 727

2. Barbosa, T. M. L.; Rigitano, R. L. O.; Pesq. Agropec. Bras. 1994, 29, 955.

3. Chaudhry, G. R.; Wheeler, W. B.; Water Sci. Technol. 1988, 20, 89.

4. USEPA; Pesticides in Groundwater Database, a Compilation of Monitoring Studies: 1971-1991. USEPA: Washington, DC, 1992.
5. Corrêa, M. M.; Lima, L. A.; Martinez, M. A.; Rigitano, R. L. O.; Sampaio, S. C.; Rev. Bras. Eng. Agríc. Ambient. 1999, 3, 217.

6. Rigitano, R. L. O.; Gouvêa, A. V.; Abstracts of the $15^{\circ}$ Congresso Brasileiro de Entomologia, Caxambu, Brazil, 1995.

7. Zhong, W. Z.; Lemley, A. T.; Spalik, J.; J. Chromatogr., A 1984, 299, 269.

8. Miles, C. J.; Delfino, J. J.; J. Chromatogr., A 1984, 299, 275.

9. Jandik, P.; Bonn, G.; Capillary Electrophoresis of Small Molecules and Ions, VCH Publishers: New York, 1993.

10. Arraéz-Román, D.; Segura-Carretero, A.; Cruces-Blanco, C.; Fernández-Gutiérrez, A.; Pest Manage. Sci. 2004, 60, 675.

11. WHO; Aldicarb, World Health Organization: Geneva, 1991.

12. Munch, J. W.; Method 531.1 Measurement of $N$-methylcarbamoyloximes and n-Methylcabamates in Water by Direct Aqueous Injection HPLC with Post Column Derivatization (Revision 3.1), EPA: Cincinnati, 1995.

13. Kazumi, J.; Capone, D. G.; Appl. Environ. Microbiol. 1995, 61, 2820.

14. Di Corcia, A.; Nazzari, M.; Rao, R.; Samperi, R.; Sebastiani, E.; J. Chromatogr., A 2000, 878, 87.

15. Nunes, G. S.; Alonso, R. M.; Ribeiro, M. L.; Barceló, D.; J. Chromatogr., A 2000, 888, 113.

16. Duarte, I. C. S.; Oliveira, L. L.; Buzzini, A. P.; Adorno, M. A. T.; Varesche, M. B. A.; J. Braz. Chem. Soc. 2006, 17, 1360.

17. Angelidaki, I.; Petersen, S. P.; Ahring, B. K. Appl. Microbiol. Biotechnol. 1990, 33, 469.

18. Chui, Q. S. H.; Zuchini, R.; Lichtig, J.; Quim. Nova 2001, 24, 374.

19. Chui, Q. S. H.; J. Braz. Chem. Soc. 2007, 18, 424.

20. Lee, P. W.; Handbook of Residue Analytical Methods for Agrochemicals; John Wiley \& Sons: Chichester, 2003.

21. Zaiat, M.; Cabral, A. K. A.; Foresti, E.; Rev. Bras. Eng. Quim. 1994, 11, 33.

22. ANVISA. Administrative rule RE No. 899, National Health Surveillance Agency: Brasília, 2003.

Received: December 4, 2007 Web Release Date: July 23, 2008

FAPESP helped in meeting the publication costs of this article. 